\title{
Environmental and economic impact of cloudburst-triggered debris flows and flash floods in Uttarakhand Himalaya: a case study
}

\author{
Vishwambhar Prasad Sati ${ }^{*}$ i] and Saurav Kumar
}

\begin{abstract}
This paper examines the environmental and economic impact of cloudburst-triggered debris flow and flash flood in four villages of Uttarkashi district, Uttarakhand Himalaya. On 18th July 2021 at 8:30 p.m., a cloudburst took place on the top of the Hari Maharaj Parvat, which triggered a huge debris flows and flash floods, affecting 143 households of four villages of downstream areas. Immediately after the cloudburst occurred, the authors visited four affected villages - Nirakot, Mando, Kankrari, and Siror. A structured questionnaire was constructed and questions were framed and asked from 143 heads of affected households on the impact of debris flows and flash floods on people's life, settlements, cowsheds, bridges, trees, forests, and arable land in and around the villages. The volume of debris, boulders, pebbles, gravels, and mud was assessed. It was noticed that all four villages got lots of destructions in terms of loss of life-people and animals, and property damage-land, crops, and infrastructural facilities. This study shows that the location of the settlements along with the proximity of the streams, which are very violent during the monsoon season, has led to the high impact of debris flow on the affected villages. We suggest that the old inhabited areas, which are located in the risk zones, can be relocated and the new settlements can be constructed in safe places using suitability analyses.
\end{abstract}

Keywords: Cloudburst, Debris flow, Flash flood, Calamity, Impact, Himalaya

\section{Introduction}

Cloudburst, a geo-hydrological hazard, refers to a sudden and heavy rainfall that takes place within a short span of time and a particular space (Sati 2013). The intensity of rainfall is often more than $100 \mathrm{~mm} / \mathrm{h}$ (Das et al. 2006). The disruptive events, cloudbursts occur during the monsoon season in the Himalaya and trigger debris flows, flash floods, landslides, and mass movements (Fig. 1). Fragile landscape, rough and rugged terrain, and precipitous slope accentuate the magnitude of geo-hydrological hazards. Cloudburst-triggered debris flows, flash floods, landslides, and mass movements have become more intensive and frequent worldwide, mainly

*Correspondence: sati.vp@gmail.com

Department of Geography and Resource Management, Mizoram

University (A Central University), Aizawl 796004, India in the mountainous regions, causing large-scale destruction of people, land, and property (Houghton et al. 1996; Wang et al. 2014; Mayowa et al. 2015; Malla et al. 2020; Sim et al. 2022). Similarly, the Himalayan region is prone to the occurrences of cloudburst-triggered hazards, causing huge loss of life and property and degradation of forest and arable lands (Bohra et al. 2006; Allen et al. 2013; Balakrishnan 2015; Ruiz-Villanueva et al. 2017).

The Uttarakhand Himalaya, one of the integrated parts of the Himalaya, is the most fragile landscape and prone to geo-hydrological hazards-cloudbursts, avalanches, and glacier bursts (Sati 2019). It receives many hazards mainly cloudburst-triggered debris flows, flash floods, landslides, and mass movements during the monsoon season every year. The intensity, frequency, and severity of these hazards have been observed to increase during the recent past. Devi (2015) stated that the changing 

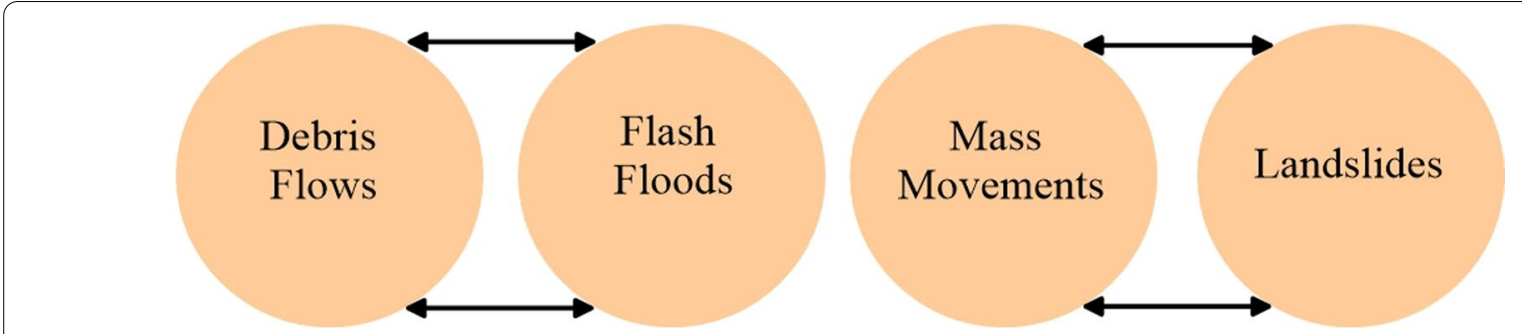

Fig. 1 Cloudburst-triggered hazards in the Uttarakhand Himalaya

monsoon patterns and increasing precipitation in the Himalaya are associated with catastrophic natural hazards. However, these hazards are the least understood because of the remoteness of the areas and lacking meteorological stations (Thayyen et al. 2013).

The Uttarakhand Himalaya has many eco-sensitive zones, vulnerable to natural hazards mainly for geohydrological hazards. Every year, many cloudburst events occur here, cause to roadblocks, land degradation, forest and cropland loss, and losses of life and infrastructural facilities. One of the most devastating cloudburst-triggered debris flow events of this century occurred on the night of 16th and 17th June 2013 in the famous Hindu pilgrimage 'Kedarnath', which killed more than 10,000 people and devastated the entire Mandakini and Alaknanda river valleys (Upadhyay 2014; Sati 2013). The entire region had received 16 major geo-hydrological and terrestrial hazards within the last 50 years (Bhambri et al. 2016). Some of the devastating cloudburst-triggered debris flows and flash floods that occurred in the Uttarakhand Himalaya are Rudraprayag on 14th September 2012, Munsiyari on 18th August 2010, Kapkot on 19th August 2010, Nachni on 7th August 2009, Malpa and Ukhimath on 17th August 1998, Badrinath on 24th July 2004, and the Alaknanda River valley on 1970. About 20,000 people died and a huge loss of property took place due to these calamities (Das 2015). It has been noticed that these catastrophic events occurred mainly during the three months of the monsoon season-July, August, and September.

Debris flows and flash floods caused by glacierbursts incidences were although not much frequent and intensive yet, during the recent past, their number has increased owing to changes in the climatic conditions. The increasing number of infrastructural facilities on the valley bottom has accelerated damages owing to exposed elements in risk-prone areas (Sati 2014; ICIMOD 2007a, b; Chalise and Khanal 2001; Bhandari 1994; Uttarakhand 2017). Many drivers exist, which affect the severity of cloudburst-triggered hazards in the Uttarakhand Himalaya. Growing population and the construction of settlements and infrastructural facilities on the fragile slopes and along the river valleys have also caused severe hazards. The Uttarakhand region is home to world-famous pilgrimages and natural tourism. Mass tourism during the rainy season enhances the intensity of disasters.

Several studies have been carried out on glacier-bursts and cloudburst-triggered debris flows and flash floods in the Himalaya (Shugar et al. 2021; Byers et al. 2018; Cook et al. 2018; Asthana and Sah 2007; Bhatt 1998; Joshi and Maikhuri 1997; NIDM 2015; IMD 2013; Khanduri et al. 2018; Sati 2006, 2007, 2009, 2011, 2018a, b, 2020; Naithani et al. 2011). These studies were conducted from broader perspectives, mostly covering the entire Himalaya. However, the present paper looks into the case study of four villages of the Uttarakhand Himalaya, which were severely affected and damaged by cloudburst-triggered debris flows and flash floods, which occurred on July 18th, 2021. It analyses the environmental impact of cloudbursts in terms of forest and fruit trees dislocation, land degradation, and soil erosion-arable, forests, and barren land of the four affected villages. It also evaluates the human and economic losses like the killing of people, loss of existing crops, and damage of houses and cowsheds, respectively. The study suggests policy measures to risk reduction and rehabilitation of settlements from danger zones to safer areas after suitability analysis.

\section{Study area}

The Uttarakhand Himalaya is located in the north of India and south of the Himalaya. It is also called the Indian Central Himalayan Region. Out of the total 93\% mountainous area, $16 \%$ is snow-capped, called the Greater Himalaya. The terrain is undulating and precipitous and the landscape is fragile, vulnerable to natural hazards. This catastrophic event occurred in the four villages of Uttarkashi district. The Uttarkashi town lies about $10 \mathrm{~km}$ downstream of the affected villages. A National Highway number 108, connecting Haridwar and Gangotri, is passing through Uttarkashi town. The four affected villages-Nirakot, Mando, Kankrari, and Siror 
are located in the upper Bhagirathi catchment, which is prone to geo-hydrological hazards. The slope gradient of these villages varies from $15^{\circ}$ to $70^{\circ}$. Indravati is a perennial stream, a tributary of the Bhagirathi River that meets Bhagirathi from its left bank. All three Gadheras (streams)-Mando, Diya, and Siror are seasonal but violent during the monsoon season. Nirakot $(1530 \mathrm{~m}$ ) village is located in the middle altitude of the Hari Maharaj Parvat $(2350 \mathrm{~m})$ in a steep slope, Mando village $(1180 \mathrm{~m})$ is located on the left bank of the Bhagirathi River along the Mando Gadhera with gentle to a steep slope, Kankrari $(1620 \mathrm{~m})$ village is located on the moderate to the gentle slope on the bank of the Diya Gadhera, and Siror village $(1280 \mathrm{~m})$ is situated on the left bank of both Bhagirathi and Siror Gadhera with gentle to the steep slope (Fig. 2). One of the prominent eco-sensitive zones of the Uttarakhand Himalaya, the 'Bhagirathi Eco-Sensitive Zone' is $120 \mathrm{~km}$ long, spanning from Uttarkashi to Gaumukh, along the Bhagirathi River valley (Sati 2018a, b). The rural people depend on the output of the traditional farming systems, often face intensive natural hazards. The settlements are located either on the fragile and steep slopes or on the banks of streams, which are very violent during the monsoon season when a heavy downpour occurs. Therefore, heavy losses of life and property in these areas are common, taking place every year.

\section{Methodology}

This study was empirically tested and a qualitative approach was employed to describe data. A structured questionnaire was constructed. The main questions framed and asked from the heads of households were-human and animal death, damage to self property-houses and cowsheds, and existing crops-cereals, fruits, and vegetables. Loss to public properties such as bridges, public institutions, and forest land was assessed. Based on the questions framed, we surveyed 143 heads of households of four villages, which were partially or fully affected due to cloudburst-triggered debris flow. These villages are Nirakot, Mando, Kankrari, and Siror. To assess the debris and the damaging areas, the authors travelled from the source areas to the depositional zones and measured the volume of debris-boulders, pebbles, sands, and soils using a formula; circumference $=2 \pi R$ and area $=\pi * R^{2}$. The slope gradient, accessibility, economic conditions, and climate of the villages were




assessed and based on which, the susceptibility analysis of the villages was carried out. The villages were divided into very high susceptibility, high susceptibility, and moderate susceptibility levels. Both environmental degradation and economic losses in four villages were assessed. We used Geographical Positioning System (GPS) to obtain the data of altitude, longitude, and latitude. Two maps-case study villages and the major cloudburst incidences-2020 and 2021 were prepared and data were also presented using graphs. Photographs of four villages were used to present the destruction of villages due to the cloudburst event.

\section{Results and analysis}

Major cloudburst incidences in the Uttarakhand Himalaya Past incidences depict that the Uttarakhand Himalaya suffered tremendously due to cloudburst-triggered calamities. We gathered data on the major cloudburst incidences in Uttarakhand in the monsoon seasons of 2020 and 2021 from the state disaster relief force (SDRF), Dehradun. From May to September 2020, 13 major cloudburst incidences were noticed in Uttarakhand (Table 1). These incidences resulted in the death of 22 people and 77 animals, and 19 houses were fully damaged. Similarly, from May to September 2021, 17 major cloudburst incidences were occurred in the Uttarakhand Himalaya, resulting in the death of 34 people and 144 animals, and 106 houses were buried. Besides, it caused a huge loss to public property and landscape degradation.

The economic losses in 2021 were much higher than the losses in 2020 (Fig. 3). In 2021, the frequency and intensity of cloudburst-triggered calamities were also higher. The loss of animals was quite high both the years. Houses that collapsed due to calamity were six times higher in 2021 than in 2020. The loss of human life was substantial in both years. Several bridges were washed away.

District-wise major cloudburst events of 2020-2021 are shown in the map of the Uttarakhand Himalaya (Fig. 4). A total of 30 major cloudburst incidences were recorded, out of which, 17 occurred in 2021. The Uttarkashi district received the highest incidences (07), followed by the Chamoli district (05). Dehradun and Pithoragarh districts have recorded 04 incidences each. Rudraprayag 03 and Tehri, Almora, Bageshwar have recorded 01 each. It has been observed that cloudburst-triggered incidences mainly occurred in remote places along the fragile river valleys and middle slopes.

\section{Case study of affected villages}

On July 18, 2021, a cloudburst hits the Hari Maharaj Parvat (hilltop) at an altitude of $2350 \mathrm{~m}$ at 8:30 p.m., which triggered huge debris flows and flash floods. The four villages-Nirakot, Mando, Kankrari, and Siror of Uttarkashi district, located down slopes of the hilltop and close to the Uttarkashi town, were severely affected due to debris flow (Table 2). At the cloudburst hit area, it formed three gullies, which later on merged into three streams, along which these villages are located. Debris, from the source i.e. hilltop of Hari Maharaj Parvat, equally flew in three directions. Since the cloudburst event occurred at 8:30 p.m., the people did not have time to move with their movable property and therefore, the magnitude of damage was enormous.

The villages are located from the altitudes of $1180 \mathrm{~m}$ (lowest) to $1620 \mathrm{~m}$ (highest). Mando village is located at $1180 \mathrm{~m}$, Kankrari village at $1620 \mathrm{~m}$, Nirakot at $1530 \mathrm{~m}$, and Siror has $1280 \mathrm{~m}$ altitude. The two villages-Nirakot and Mando have west-facing slopes, Kankrari has a south-facing slope, and Siror has a north-facing slope. These villages are located along the tributaries of the Bhagirathi River, with 2 to $5 \mathrm{~km}$ distance from the road. The intensity and volume of debris were different in different villages, therefore, the casualties and losses were also varied. The villages are surrounded by agricultural and forestlands. The farmers mainly grow subsistence cereal crops-paddy, wheat, pulses, oilseeds, fruits, and vegetables. Forest types comprise pine (sub-tropical) and oak and coniferous forests (temperate), used for fodder, firewood, and wild fruits.

Located at the high-risk zones, these villages face several disaster incidences every year. Out of the total 143 heads of households surveyed, more than $80 \%$ of heads were in favour of rehabilitating them in the safer areas. They wanted to relocate their houses and cowshed within the village territory with financial assistance from the state government. The streams, along which the settlements are constructed, are fragile and highly vulnerable to landslide hazards. Further, the cloudburst incidences are increasing due to climate change, the heads of households perceived.

Figure 5 shows four villages-Nirakot, Mando, Kankrari, and Siror, which were severely affected by cloudburst-triggered debris flow and flash flood. The volume of debris and boulders can be seen in all the villages. These villages are surrounded by dense sub-tropical and temperate forests that vary from pine to mixed-oak and deodar. Kharif crops were growing in the arable land whereas a large cropland has been washed away.

\section{Impact of cloudburst-triggered debris flow and flash flood Environmental impact}

The environmental impact of cloudburst-triggered debris flow and flash flood in four villages of Uttarkashi district was analyzed (Table 3). The major variables were the number of forest trees dislocated, total land degradation, 
Table 1 Major cloudbursts occurred in Uttarakhand in 2020 and 2021. Source: SDRF (2021)

\begin{tabular}{|c|c|c|}
\hline Date of occurrence & Cloudburst hit area & Casualties \\
\hline \multicolumn{3}{|l|}{ April-August 2020} \\
\hline April 23, 2020 & Kotdwar (Pauri district) & Low-lying areas were flooded and arable land was washed away \\
\hline April 27, 2020 & Naugaon and Mori (Uttarkashi district) & Five houses were partially damaged and agricultural land flown \\
\hline July 14, 2020 & Dharchula (Pithoragarh) & Landslide on the road connecting India-Tibet boarder \\
\hline July 19,2020 & Madkot and Tanga (Pithoragarh) & Three people were killed and six injured \\
\hline July 20,2020 & Bata, Sirtaul, and Munsiyari & $\begin{array}{l}\text { Eight houses were buried, three people killed, } 10 \text { cattle died, and bridges and } \\
\text { farmlands washed away }\end{array}$ \\
\hline July 28,2020 & Banagapani (Uttarkashi) & 47 cattle died \\
\hline July 28, 2020 & Ghat (Chamoli district) & Three houses flown, cowsheds collapsed, and three people died \\
\hline August 9, 2020 & Gangi village (Tehri) & 20 cattle were buried \\
\hline August 10, 2020 & Sirwadi (Rudraprayag) & Seven houses were fully damaged \\
\hline August 10, 2020 & Bageshwar & A house was collapsed and a bridge flown \\
\hline August 18, 2020 & Mori village (Uttarkashi) & 12 people died \\
\hline August 19, 2020 & Near Lakhwar Dam (Uttarkashi) & A bridge was collapsed \\
\hline August 24, 2020 & Tali-Ansari (Chamoli) & One person died and one injured \\
\hline \multicolumn{3}{|l|}{ May-July 2021} \\
\hline May 3, 2021 & Kumrada, Baldogi, and Kamad (Uttarkashi) & Three people died \\
\hline May 3, 2021 & Narkota (Rudraprayag) & On Three houses damaged and 1-acre arable land was washed away \\
\hline May 3, 2021 & Khankra, Fatehpur Kotli, Gairsari Narkota & One person died \\
\hline May 11, 2021 & Devprayag town & Sixteen buildings were collapsed \\
\hline May 20, 2021 & Bijnad, Chakrata & Three people and 24 animals died \\
\hline May 30, 2021 & Bangwari village (Pauri) & $\begin{array}{l}\text { Two cows died and } 0.5 \text {-acre agricultural land washed away, exiting crops dam- } \\
\text { aged and fruit trees dislocated }\end{array}$ \\
\hline July $18,2021^{*}$ & Nirakot & $\begin{array}{l}\text { One person died, } 0.7 \text {-acre arable land washed away and three buildings and } 5 \\
\text { bridges collapsed }\end{array}$ \\
\hline July $18,2021^{*}$ & Mando & $\begin{array}{l}\text { Three people and two animals died, 1.2-acre arable land washed away, and five } \\
\text { buildings and two bridges collapsed }\end{array}$ \\
\hline July $18,2021^{*}$ & Kankrari & $\begin{array}{l}\text { One person died, 20.6-acre arable land was washed away, } 11 \text { buildings were dam- } \\
\text { aged, and } 6 \text { bridges collapsed }\end{array}$ \\
\hline July $18,2021^{*}$ & Siror & 0.6-acre arable land flown and one bridge collapsed \\
\hline August 07, 2021 & Khirsu & 50 cattle died, six cowsheds collapsed \\
\hline August 08, 2021 & The Valley of Flowers & 20-m pathways and a footbridge was washed away \\
\hline August 13, 2021 & Marchula (Almora) & Houses, cowsheds, water pipes, and a road was washed away \\
\hline August 27, 2021 & Bihar (Vikas Nagar) & Vyasi hydropower project was impacted \\
\hline August 30, 2021 & Jumma village (Dharchula) & Seven people died \\
\hline September 7, 2021 & Syunsad village (Pauri) & Farmlands and crops were damaged \\
\hline September 20, 2021 & Panti village (Chamoli) & $\begin{array}{l}\text { Houses, shops, and cowsheds were washed away. Karnprayag-Gwaldom road was } \\
\text { blocked for several days }\end{array}$ \\
\hline
\end{tabular}

*Present case study villages

land degradation under existing crops, number of fruit trees dislocated, land degradation under arable land, number of buildings were damaged, number of bridges damaged, and boulders' volume. Forest trees, which dislocated were pine in the middle altitude and mixed-oak and deodar in the higher altitude. A total of 770 forest trees were dislocated from all four villages, out of which, 500 were from the Kankrari village (highest). The lowest trees dislocated were from Siror village (70). The total land degradation from the cloudburst hit areas to the affected areas was huge, however, we have measured the land which was within and surrounding each village. The total land degradation was 52.5 acres with the highest in Kankrari (45 acres) and the lowest in Siror (0.5 acres). The land degradation under existing crops was 22.6 acres in all four villages, varying from 0.1 acres in Siror to 20.6 acres in Kankrari. The total number of fruit trees dislocated was 486. Land degradation under arable land was 22.6 acres. It includes the area under existing crops both agriculture and horticulture. A total of 19 buildings were 


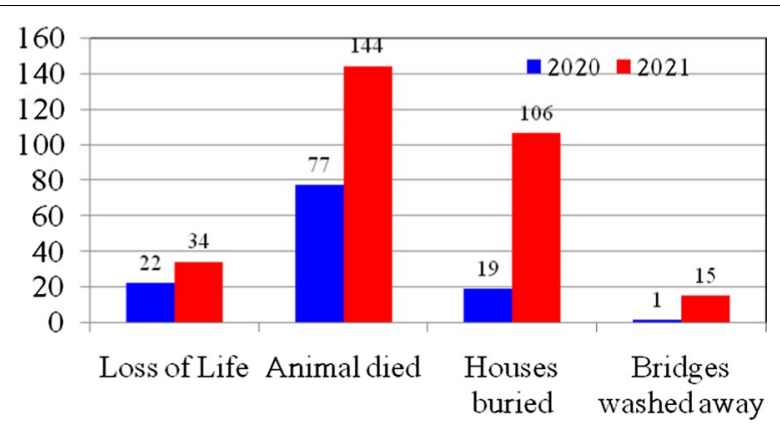

Fig. 3 Loss of human lives, livestock, houses and bridges due to cloudburst in Uttarakhand during the 2020 and 2021

damaged whereas a total of 14 bridges, connecting the affected villages were washed away.

\section{Economic impact}

The economic impact due to cloudburst calamity was tremendous in the forms of a household affected, loss of human and animal life, building loss, forest loss, loss of existing crops including fruits, loss of arable land, and loss of bridges (Table 4). The value of all these assets was calculated in Indian Rupees (INR) at the current price. The total number of households affected was 143, of which, 100 households belonged to the Kankrari village (highest) and three households (lowest) were from Siror village. Four people died due to the calamity-three women from Mando village and 1 man from Kankrari village. Two cows from Mando village died. The total loss from the collapse of the building was 1.7 million INR, with the highest (1.1 million INR) from Kankrari village. A total of 0.77 million INR was lost due to forest loss, and the loss from existing crops was 3.35 million INR. Loss from dislocation of fruit trees was noted high, which was about 0.5 million INR. A large portion of arable land was flown which value was 11.3 million INR. About 14 million INR was lost due to the collapse of bridges. As a whole, about 31.62 million INR was lost due to cloudburst calamity. Per household loss by the cloudburst calamity was noted 0.22 million INR.

\section{Average circumference, area, and volume of boulders}

We calculated the average circumference, area, and volume of boulders in the case study villages using a formula: circumference $=2 \pi R$; Area $=\pi * R^{2}$; volume $=$ length $\times$ width $\times$ depth (Table 5). We noticed that

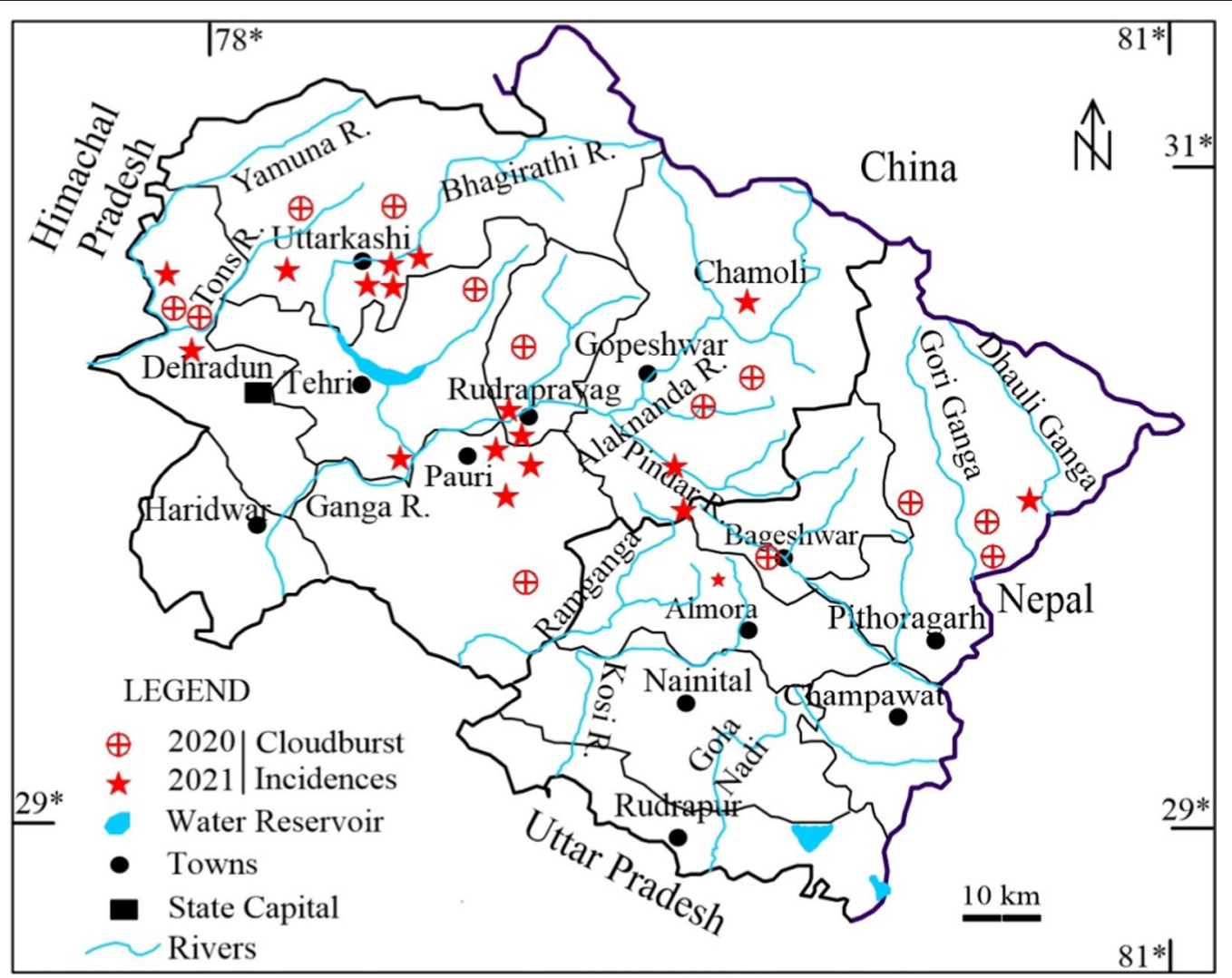

Fig. 4 Location map of cloudbursts hit areas in 2020 and 2021 


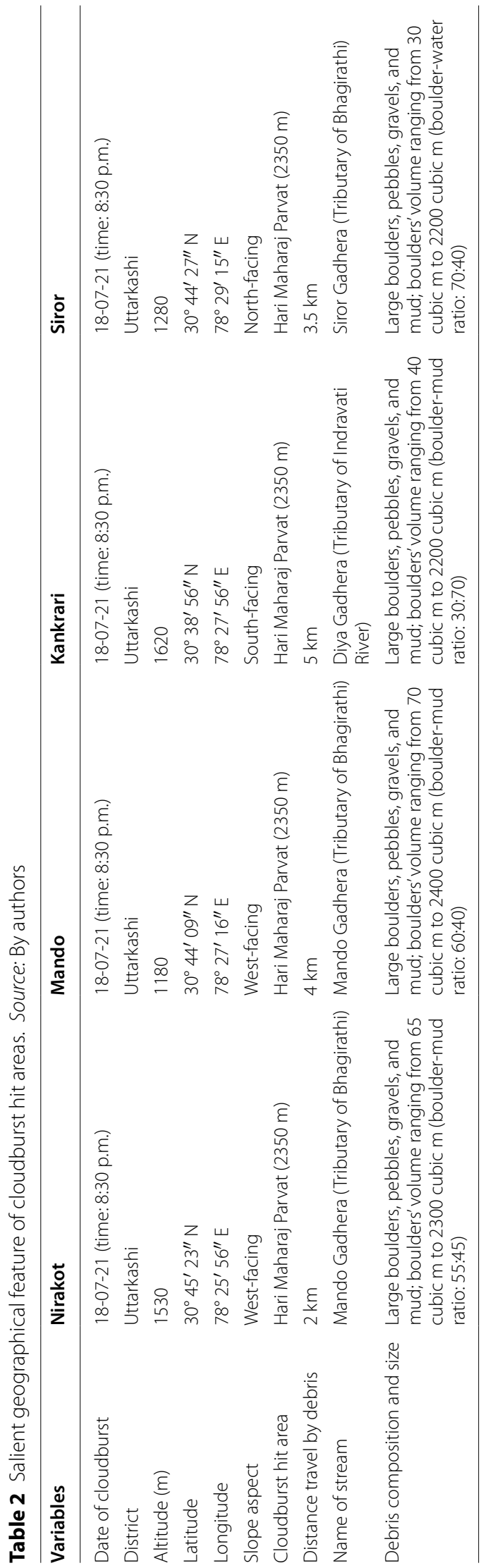


(a)

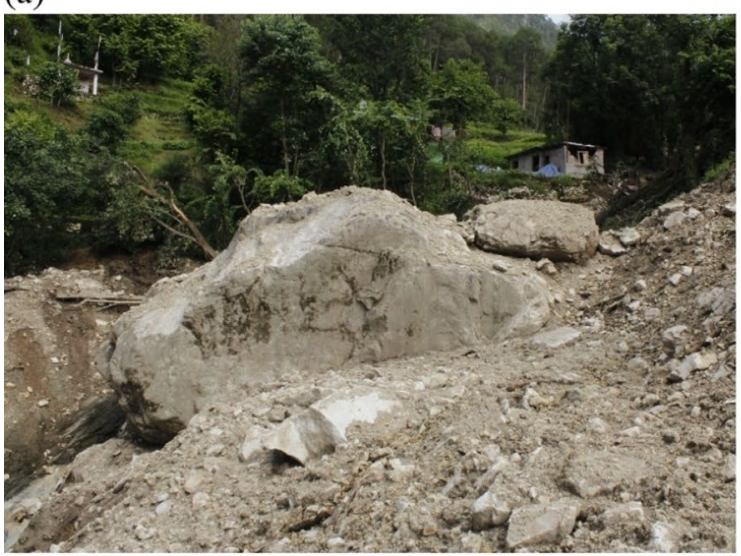

(c)

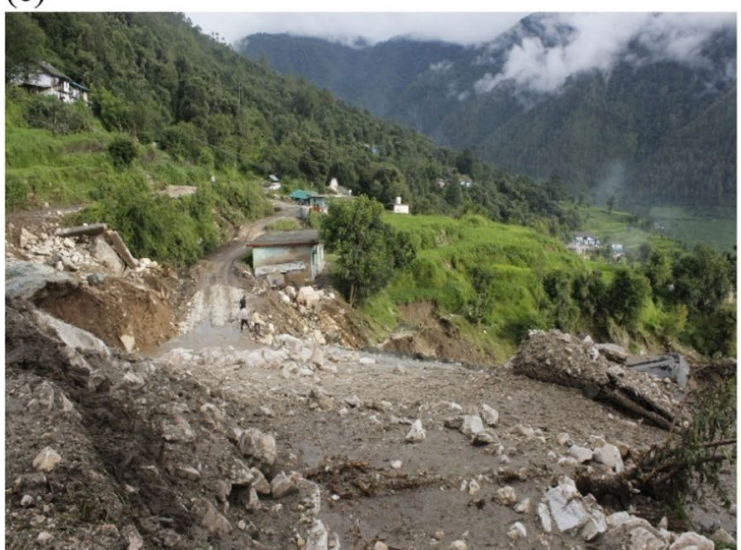

(b)

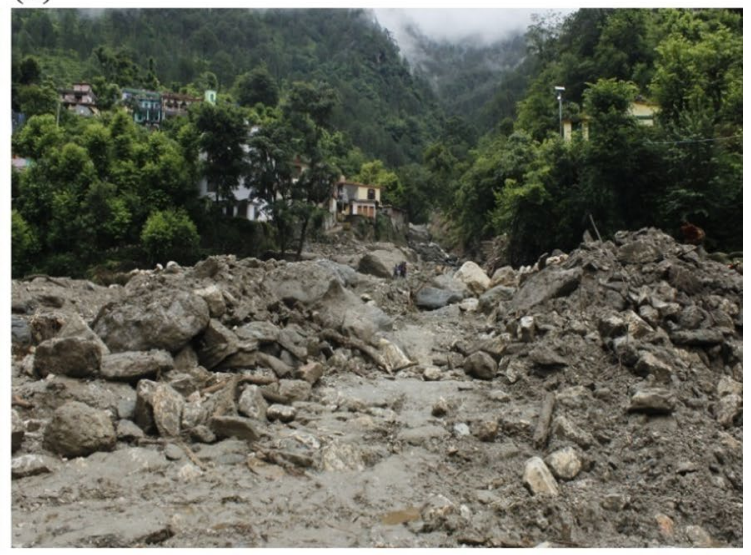

(d)

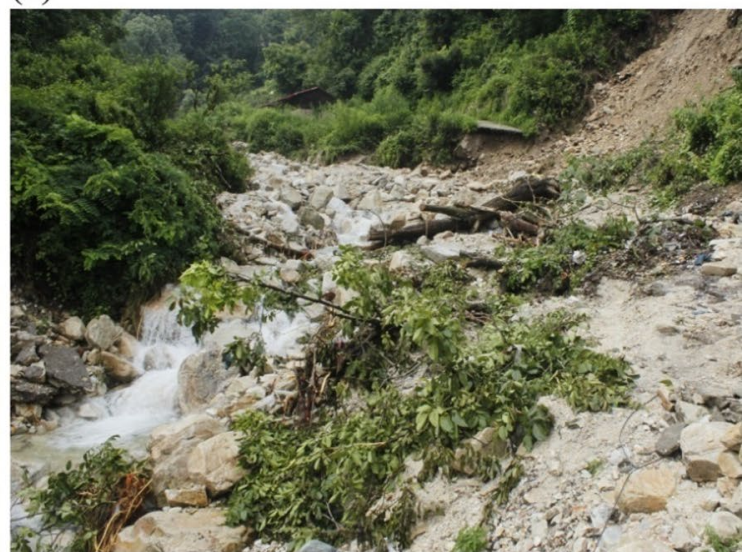

Fig. 5 Cloudburst affected villages a Nirakot, b Mando, c Kankrari, d Siror; Photo: by authors

Table 3 Environmental impact of cloudburst-triggered debris flow and flash flood. Source: by authors

\begin{tabular}{|c|c|c|c|c|c|}
\hline Variables & Nirakot & Mando & Kankrari village & Siror & Total \\
\hline Number of forest trees dislocated & 100 & 100 & 500 & 70 & 770 \\
\hline Total land degradation (acre) & 2 & 4 & 45 & 0.5 & 51.5 \\
\hline Land degradation under existing crops (acre) & 0.7 & 1.2 & 20.6 & 0.1 & 22.6 \\
\hline Number of fruit trees dislocated & 162 & 20 & 300 & 4 & 486 \\
\hline Land degradation under arable land (acre) & 0.7 & 1.2 & 20.6 & 0.1 & 22.6 \\
\hline Number of buildings damaged & 3 & 5 & 11 & Nil & 19 \\
\hline Number of bridges damaged & 5 & 2 & 6 & 1 & 14 \\
\hline
\end{tabular}

the highest average area of boulders was in Mando village, which is $28.3 \mathrm{~m}^{2}$ followed by Kankrari $19.6 \mathrm{~m}^{2}$, Nirakot $12.57 \mathrm{~m}^{2}$, and Siror $7.1 \mathrm{~m}^{2}$. In terms of the total volume of debris, it was the highest in Kankrari village, followed by Mando, Nirakot, and Siror villages.

Figure 6 shows the average diameter of boulders in the cloudburst-affected villages. We drew the figure with a scale of $1 \mathrm{~cm}$ is equal to $1 \mathrm{~m}$. The average biggest diameter of boulders was found in Mando village (6 m), followed by Kankrari $(5 \mathrm{~m})$ and Nirakot $(4 \mathrm{~m})$ villages. The average smallest diameter of boulders was found in Siror village $(3 \mathrm{~m})$.

\section{Susceptibility analysis}

Based on the above description, susceptibility analysis of the case study villages was carried out (Table 6). 
Table 4 Economic impact of cloudburst-triggered debris flow and flash flood. Source: By authors

\begin{tabular}{llllll}
\hline Variables & Nirakot & Mando & Kankrari & Siror & Total \\
\hline Number of affected HHs & 22 & 18 & 100 & 03 & 143 \\
Loss of human life & $\mathrm{Nil}$ & 3 & 1 & $\mathrm{Nil}$ & 04 \\
Loss of animals (cows) & $\mathrm{Nil}$ & 2 & $\mathrm{Nil}$ & $\mathrm{Nil}$ & 02 \\
Building loss (million INR) & 0.25 & 0.45 & 1.1 & $\mathrm{Nil}$ & 1.7 \\
Forest loss (million INR) & 0.1 & 0.1 & 0.5 & 0.07 & 0.77 \\
Crops loss (million INR) & 0.4 & 0.8 & 1.4 & 0.75 & 3.35 \\
Loss of fruits (million INR) & 0.162 & 0.02 & 0.3 & 0.004 & 0.5 \\
Loss of arable land (million & 0.35 & 0.6 & 10.3 & 0.05 & 11.3 \\
INR) & & & & & \\
Loss of Bridges (million INR) & 5 & 2 & 6 & 1 & 14 \\
Total (INR) & 6.26 & 3.97 & 19.6 & 1.87 & 31.62 \\
\hline
\end{tabular}

Table 5 Average circumference, area, and volume of boulders. Source: By author

\begin{tabular}{lllll}
\hline Variables & Nirakot & Mando & Kankrari & Siror \\
\hline Radius $(\mathrm{m})$ & 2 & 3 & 2.5 & 1.5 \\
Diameter $(\mathrm{m})$ & 4 & 6 & 5 & 3 \\
Circumference $(\mathrm{m})$ & 12.57 & 18.8 & 15.7 & 9.4 \\
Area $\left(\mathrm{m}^{2}\right)$ & 12.57 & 28.3 & 19.6 & 7.1 \\
$\begin{array}{l}\text { Total volume of debris } \\
\text { (cubic } \mathrm{m})\end{array}$ & 36,000 & 48,000 & 62,000 & 24,000 \\
\hline
\end{tabular}

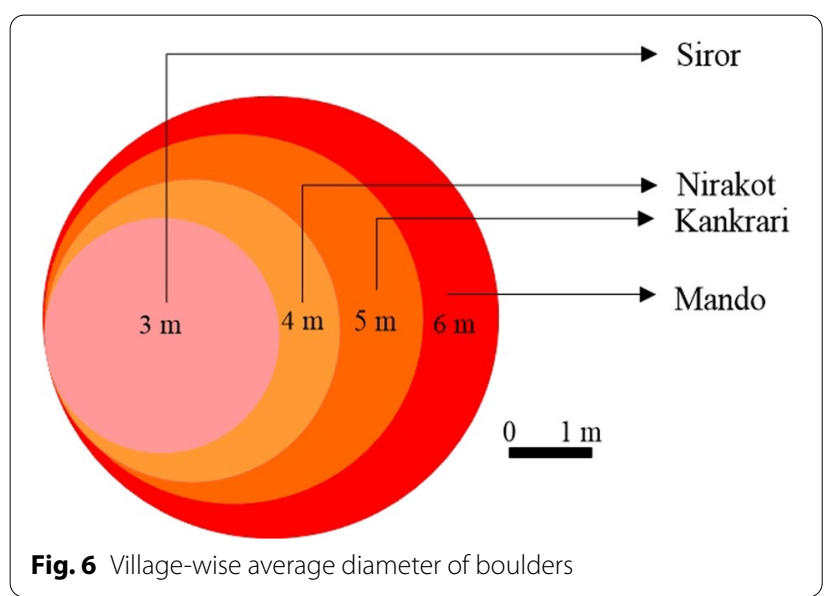

The main variables of susceptibility were slope gradient, accessibility of villages, economic conditions of households, and climatic conditions. We noticed that Nirakot village has very high susceptibility, Kankrari has high, and Siror and Mando have moderate susceptibility.

\section{Discussion}

The Uttarakhand Himalaya is highly vulnerable to geohydrological disasters because of its geological formation (Vaidya 2019). It is an ecologically fragile, geologically sensitive, and tectonically and seismically very active mountain range (Sati 2019). The geo-hydrological events-cloudbursts and glacier bursts-triggered catastrophes are very common and devastating. The monsoon season poses severe threats to natural hazards because of heavy downpours. About 93\% of the Uttarakhand Himalaya is mountainous mainland, of which $16 \%$ is snowcapped. The undulating and precipitous terrain and remoteness are the most vulnerable for disaster risks.

This study reveals that most of the cloudbursts incidences in 2020-21 occurred mainly in the remote mountainous districts of the Uttarakhand Himalaya. The villages in the Uttarakhand Himalaya are located on the sloppy land and along the river valleys, which are fragile and very vulnerable to disasters. The rivers flow above danger marks during the monsoon season cause threats to rural settlements. The roads of Uttarakhand are constructed along the river banks and on fragile lands. These roads lead to the highland and river valley pilgrimages where the number of tourists and pilgrims visit every year mainly during the monsoon season. There are many locations along the river valleys where the houses are constructed on the debris, deposited by rivers during debris flow events. Therefore, the environmental and economic losses due to debris flows and flash floods are high. The construction of hydropower projects along the river valleys without using sufficient technology further accentuates the vulnerability of debris flows and flash floods. One of the recent examples is the Rishi Ganga tragedy in Chamoli district where more than 200 people died with a huge loss to property (Sati 2021). We observed that the cloudburst triggered calamity in 2021 was higher than in 2020. The trend of occurring natural hazards has been increasing. Similarly, the intensity and frequency of natural hazards were observed high.

The present study shows that the environmental and economic loss in the four villages of the Bhagirathi River valley was huge due to cloudburst-triggered debris flows and flash floods. Almost every household of the villages were affected by cloudburst calamity. There were large forest and arable land degradation, forest and fruit trees were dislocated, loss of lifehuman and animal, and the houses and bridges were collapsed. The calamity also poses threat to the future, in terms of, the large deposition of debris including boulders, pebbles, and gravels in the villages along the streams and gullies. The rural people are poor and their livelihood is dependent on practicing subsistence agriculture. Many of them are living below the poverty line 
Table 6 Susceptibility analysis of case study villages. Source: By authors

\begin{tabular}{lllll}
\hline Variables & Nirakot & Mando & $\begin{array}{l}\text { Kankrari (including Sada and } \\
\text { Thalan) }\end{array}$ & Siror \\
\hline Slope gradient & $30^{\circ}-55^{\circ}$ & $30^{\circ}-55^{\circ}$ & $30^{\circ}-45^{\circ}$ & $20^{\circ}-30^{\circ}$ \\
Accessibility & Highly inaccessible & Accessible & Inaccessible & Accessible \\
Economic condition & Not favourable & Average & Not favourable & Average \\
Climate & Cold in winter & Conducive & Cold in winter & Conducive \\
Susceptibility & Very high & Moderate & High & Moderate \\
\hline
\end{tabular}

in these villages. Because the existing crops have been lost, they are facing food insecurity. Further, the psychological problems are immense. The fear of another calamity is always there in the mind of people as all villages are situated in very high to moderate susceptible areas. The national highway is passing through the right bank of the Bhagirathi River and the affected villages are situated on the left bank. The connectivity problem is immense all the time in these villages. The entire rural areas of the Uttarakhand Himalaya are facing similar problems.

\section{Conclusion}

Cloudburst-triggered debris flows and flash floods are natural calamities in the Himalayan regions. They occur naturally and cannot be stopped. The losses-environmental and economic are also huge. However, the severity of these natural calamities can be minimized. For example, the high impact of cloudburst-triggered debris flow on the four study villages was mainly due to their location along the streams and on the fragile slopes. This can be avoided by constructing the settlements in safer places generally away from the violent streams. In the disaster risk zones, scenario analysis can be carried out under which, identifying driving forces of disaster risks is the first step. Then, the critical uncertainties are to be identified, and finally, a possible scenario can be developed. Nature-based eco-disaster risk reduction can be adopted to prevent further disaster risks. A large-scale plantation drive in the degraded land will restore the fragile landscape. Both pre and post-disaster risk reduction measures can be adopted to reduce the economic and environmental impact of debris flows. There must be policies implementation programmes for providing immediate relief packages for the affected people in terms of food and shelters. In a long run, susceptibility analyses should be carried out to understand the risk to the settlements so that the settlements can be replaced on the safer side if needed. A special budget can be allocated to hazard-prone villages during adverse situations.

\section{Authors' contributions}

The first author analyzed data, prepared maps, and diagrams, and wrote the manuscript. The second author conducted a field survey and collected data. All authors read and approved the final manuscript.

\section{Declarations}

\section{Ethics approval}

This article does not contain any studies with human participants performed by any of the authors.

\section{Competing interests}

There is no competing interests in the manuscript.

Received: 20 September 2021 Accepted: 15 February 2022

Published online: 24 February 2022

\section{References}

Allen SK, Rastner P, Arora M, Huggel C, Stoffel M (2013) Lake outburst and debris flow disaster at Kedarnath, June 2013: hydrometeorological triggering and topographic predisposition. Landslides 13(6):1479-1491

Asthana AKL, Sah MP (2007) Landslides and cloudbursts in the Mandakini Basin of Uttarakhand Himalaya. Himal Geol 28:59-67

Balakrishnan S (2015) Chennai flood of 1-5 December 2015: an extreme climatic event? Curr Sci 110(1):9

Bhambri R, Mehta M, Dobhal DP, Gupta AK, Pratap B, Kesarwani K, Verma A (2016) Devastation in the Kedarnath (Mandakini) Valley, Uttarakhand Himalaya, during 16-17 June 2013: a remote sensing and ground-based assessment. Nat Hazards 80:1801-1822

Bhandari RK (1994) Landslide hazard mapping in Sri Lanka-a holistic approach. In: Proceeding of national symposium on landslides in Sri Lanka, pp 271-284

Bhatt O (1998) Living in the shadows of death: landslides in Uttrakhand. The calamity-prone Central Himalayas, Lok Soochana Evam Sahayata Kendra, Gopeshwar, Chamoli, Uttarakhand, India, pp 1-4

Bohra AK, Basu S, Rajagopal EN, lyengar GR, Gupta MD, Ashrit R, Athiyaman B (2006) Heavy rainfall episode over Mumbai on 26 July 2005: assessment of NWP guidance. Curr Sci 90(9):1188

Byers AC, Rounce DR, Shugar DH, Lala JM, Byers EA, Regmi D (2018) A rock fallinduced glacial lake outburst flood, Upper Barun Valley, Nepal. Landslides 16:533-549. https://doi.org/10.1007/s10346-018-1079-9

Chalise SR, Khanal NR (2001) An introduction to climate, hydrology and landslide hazards in the Hindu Kush-Himalayan Region. In: Tianchi L, Chalise SR, Upreti BN (eds) Landslide hazard mitigation in the Hindu Kush-Himalayas. ICIMOD, Kathmandu, pp 51-62

Cook KL, Andermann C, Gimbert F, Adhikari BR, Hovius N (2018) Glacier lake outburst floods as drivers of fluvial erosion in the Himalaya. Science 362:53-57 
Das PK (2015) Global warming, glacial lakes and cloud burst events in Uttarakhand-Kumaon Himalaya: a hypothetical analysis. Int J Environ Sci 5(4):697-708

Das S, Ashrit R, Moncrieff MW (2006) Simulation of a Himalayan cloudburst event. J Earth Syst Sci 115(3):299-313. https://doi.org/10.1007/BF027 02044

Devi R (2015) Spatio temporal occurrences of cloud burst In the Himachal Himalaya. Int J Res Soc Sci 5(1):886-894

Houghton JT et al (1996) The IPCC second assessment report. In: Houghton JT, Meira Filho LG, Callander BA, Harris N, Kattenberg A, Maskell K (eds) Climate change. Cambridge University Press, New York, p 572

ICIMOD (2007a) Inventory of glaciers, glacial lakes and identification of potential glacial lake outburst flood (GLOFs) affected by global warming in the mountains of the Himalayan Region (DVD ROM). ICIMOD, Kathmandu

ICIMOD (2007b) Flash flood hotspot mapping in the Hindu Kush-Himalayan region (draft DVD ROM). ICIMOD, Kathmandu

IMD (2013) A preliminary report on heavy rainfall over Uttarakhand during 16-18 June, 2013. India Meterological Department, Ministry of Earth Sciences, New Delhi

Joshi V, Maikhuri RK (1997) Cloudburst: a natural calamity — a case study from Uttarakhand Himalaya, UP. J Indian Build Congr 4:207-217

Khanduri S, Sajwan KS, Rawat A, Dhyani C, Kapoor S (2018) Disaster in Rudraprayag District of Uttarakhand Himalaya: a special emphasis on geomorphic changes and slope instability. J Geogr Nat Disasters 8:1-10

Malla SB, Dahal RK, Hasegawa S (2020) Analyzing the disaster response competency of the local government official and the elected representative in Nepal. Geoenviron Disasters 7:15. https://doi.org/10.1186/ s40677-020-00153-z

Mayowa O, Pour SH, Mohsenipour S, Harun M, Heryansyah SB, Ismail HT (2015) Trends in rainfall and rainfall-related extremes in the east coast of peninsular Malaysia. J Earth Sys Sci 124(8):1609-1622

Naithani AK, Rawat GS, Nawani PC (2011) Investigation of landslide events on 12th July 2007 due to cloudburst in Chamoli District, Uttarakhand, India. Int J Earth Sci Eng 4:777-786

NIDM (2015) Uttarakhnd disaster 2013. National Institute of Disaster Management Ministry of Home Affairs, Government of India, New Delhi

Ruiz-Villanueva V, Allen S, Arora M, Goel NK, Toffel M (2017) Recent catastrophic landslide lake outburst floods in the Himalayan mountain range. Prog Phys Geogr 41(1):3-28

Sati VP (2006) Natural hazards in an ecologically mountain terrain: a case for the Pindar Basin of Uttarancal Himalaya. ENVIS Himal Ecol 14(1):22-30

Sati VP (2007) Environmental impacts of debris flows - a case study of the two debris-flow zones in the Uttarakhand Himalaya. In: Chen-lung C, Major JJ (eds) Debris-flow hazards mitigation: mechanics, prediction, and assessment. Science Publishers, Rotterdam, pp 715-723

Sati VP (2009) Atmospheric and terrestrial natural calamities in the Himalaya: several devastating incidences overview. In: Proceedings of international conference on 'mitigation of natural hazards in mountain areas'Bishkek, SALAM, Kyrgyzstan. http://www.geomin.cz/conference/menu/Sati_ paper_eng.pdf. (in Russian)

Sati VP (2011) Climate disasters in the himalaya: risk and vulnerability. In: International conference on climate change and natural hazards in mountain areas. Dushanbe, Sept. 19-21, 2011. http://www.mountainhazards2011. com/souboryeditor/Paper\%20Vishwambhar\%20P.\%20Sati.pdf

Sati VP (2013) Extreme weather-related disasters: a case study of two flashfloods hit areas of Badrinath and Kedarnath valleys, Uttarakhand Himalaya, India. J Earth Sci Eng 3:562-568

Sati VP (2014) Landscape vulnerability and rehabilitation issues: a study of hydropower projects in the Uttarakhand region, Himalaya. Nat Hazards 75(3):2265-2278. https://doi.org/10.1007/s11069-014-1430-y

Sati VP (2018a) Cloudburst triggered natural hazards in Uttarakhand Himalaya: mechanism, prevention and mitigation. Int J Geol Environ Eng 12(1):45-38

Sati VP (2018b) Carrying capacity analysis and destination development: a case study of gangotri tourists/pilgrims' circuit in the Himalaya. Asia Pac J Tour Res APJTR 23(3):312-322. https://doi.org/10.1080/10941665.2018. 1433220

Sati VP (2019) Himalaya on the threshold of change, advances in global change research series, scopus indexed. Springer International Publishers, Bern
Sati VP (2020) Increasing incidences of cloudburst triggered debris-flows/ flash floods in Uttarakhand Himalaya, India. Int J Interdiscip Res Innov $8(2): 8-16$

Sati VP (2021) Are hydropower projects sustainable in Uttarakhand? Himachal Star, Feb 10, 2021, P 2, Dehradun; Delhi Post, March 01, 2021. https://delhi postnews.com/are-hydropower-projects-sustainable-in-uttarakhand/

Shugar DH, Jacquemart M, Shean D et al (2021) A massive rock and ice avalanche caused the 2021 disaster at Chamoli, Indian Himalaya. Science 373:300-306

Sim KB, Lee ML, Wong SY (2022) A review of landslide acceptable risk and tolerable risk. Geoenviron Disasters 9:3. https://doi.org/10.1186/ s40677-022-00205-6

Thayyen RJ, Dimri AP, Kumar P, Agnihotri G (2013) Study of cloudburst and flash floods around Leh, India, during August 4-6, 2010. Nat Hazards 65(3):2175-2204

Upadhyay K (2014) A year later, no lessons learnt. The Hindu (available at 498 https://www.thehindu.com/opinion/op-ed/a-year-later-no-lessons499 learnt/article6120397.ece). 500

Uttarakhand (2017) Retreat from http://www.q8india.com/blog/2017/08/15/ uttarakhandcloudburst

Vaidya RA (2019) Disaster risk reduction and building resilience in the Hindu Kush Himalaya. In: Wester P, Mishra A, Mukherji A, Shrestha A (eds) The Hindu Kush Himalaya assessment. Springer, Cham. https://doi.org/10. 1007/978-3-319-92288-1_11

Wang XJ, Zhang JY, Shahid S, Guan EH, Wu YX, Gao J (2014) Adaptation to climate change impacts on water demand. Mitig Adapt Strat Glob Change. https://doi.org/10.1007/s11027-014-9571-6

\section{Publisher's Note}

Springer Nature remains neutral with regard to jurisdictional claims in published maps and institutional affiliations.

\section{Submit your manuscript to a SpringerOpen ${ }^{\circ}$ journal and benefit from:}

- Convenient online submission

- Rigorous peer review

- Open access: articles freely available online

- High visibility within the field

- Retaining the copyright to your article

Submit your next manuscript at $\boldsymbol{\nabla}$ springeropen.com 